\title{
Adenoviral-mediated Gene Transfer to Rabbit Synovium In Vivo
}

Blake J. Roessler, * Edward D. Allen, ${ }^{\star}$ James M. Wilson, ${ }^{*}$ John W. Hartman, * and Beverly L. Davidson * Department of Internal Medicine, Divisions of ${ }^{*}$ Rheumatology and ${ }^{\ddagger}$ Molecular Medicine and Genetics, and the ${ }^{\S}$ Howard Hughes Medical Institute, University of Michigan Medical Center, Ann Arbor, Michigan 48109-0680

\begin{abstract}
Currently, treatment for rheumatoid arthritis and other inflammatory arthropathies is often inefiective in ameliorating the progression of the disease, particularly the invasive destruction of cartilage and bone by rheumatoid synovium. Multiple aspects of this inflammatory process are mediated by the synovial lining cells (synoviocytes). Genetic modification of these cells in vivo represents a potential method for the treatment of these conditions. In this report, we describe a novel technique for the genetic transduction of synovial lining cells in vivo using recombinant adenoviral vectors and intraarticular injection techniques. Purified high titer suspensions of a recombinant adenoviral vector containing the gene for Escherichia coli $\beta$-galactosidase (AdCMVlacZ) were directly injected into the hind knees of New Zealand white rabbits. Synovial tissues were then examined for transgenic lac $Z$ expression using a combination of in situ staining for $\beta$-galactosidase activity, immunohistochemical staining, and transmission electron microscopy. High efficiency gene transfer and lac $Z$ expression was observed in both type $A$ and type $B$ synoviocytes throughout the articular and periarticular synovium of the rabbit knee, with continued expression of transgenic lacZ detected for $\geq 8 \mathrm{wk}$ after infection. (J. Clin. Invest. 92:1085-1092.) Key words: synoviocytes • adenoviridae $\cdot$ lacZ $\bullet$ transduction
\end{abstract}

\section{Introduction}

Among acquired autoimmune conditions are the inflammatory arthropathies, a heterogeneous group of diseases that in the case of rheumatoid arthritis alone affects $\geq 1 \%$ of the population (1). In general, these diseases are characterized by abnormal proliferation of the specialized epithelial cells known as synoviocytes that form the lining tissue of the intraarticular space of diarthrodial joints (2). Based on morphological and functional criteria, synoviocytes have been characterized as type A (also referred to as type I) or type B (also referred to as type II) cells $(3,4)$. Type A synoviocytes are presumably derived from macrophage/monocyte precursors, exhibit phago-

Address correspondence and reprint requests to Blake J. Roessler, M.D., University of Michigan Medical Center, 5520 MSRB I, 1150 West Medical Center Drive, Ann Arbor, MI 48109-0680. 1993.

Received for publication 1 March 1993 and in revised form 11 May

J. Clin. Invest.

(c) The American Society for Clinical Investigation, Inc.

0021-9738/93/08/1085/08 $\$ 2.00$

Volume 92, August 1993, 1085-1092 cytic activity, and may function as antigen presenting cells. Type B cells are more fibroblast-like in appearance and are associated with the production of hyaluronic acid and other components of joint fluid (5).

Alterations in the normal biology of the synoviocytes are important in the development and maintenance of the pathologic process associated with rheumatoid arthritis, including invasion and destruction of articular cartilage and bone (6-8). In addition to the production of elastase and collagenase, synoviocytes mediate this pathophysiologic process by producing and upregulating the expression of cell surface proteins important in the recruitment and activation of lymphocytes and macrophages within rheumatoid synovium (9-12).

The directed overexpression of biologically active antiinflammatory proteins by synoviocytes would be a potential therapeutic intervention designed to prevent the inflammatory cascade and the development of the transformed synoviocyte phenotype associated with rheumatoid arthritis $(2,6)$. Somatic cell gene transfer to synoviocytes in vivo would be one method to accomplish this goal. Synoviocytes are easily accessed via the intraarticular space, are relatively long lived, and thus represent an ideal target for gene transfer vectors. Because synoviocytes normally have a low rate of cell turnover in vivo, they are more suitable for genetic transduction with recombinant adenoviruses rather than retroviruses (vectors that require cell division for proviral integration and transgene expression). The feasibility of using recombinant adenoviruses for direct gene transfer to synoviocytes in vivo is addressed in this report, where we describe long term expression of lacZ by rabbit synoviocytes after intraarticular infection with a recombinant adenoviral vector containing the gene for Escherichia coli $\beta$-galactosidase.

\section{Methods}

Recombinant adenoviral vectors. Replication defective adenoviral vectors are deleted of sequences spanning E1 A, E1B, and a portion of the E3 region, impairing the ability of this virus to replicate or transform nonpermissive cells (13). In the vector AdCMVlacZ, the early enhancer/promoter of the cytomegalovirus $(\mathrm{CMV})^{1}$ was used to drive transcription of lacZ with an SV40 polyadenylation sequence cloned downstream from this reporter. A more detailed description of this virus is provided elsewhere. We used an identically derived Ad5 adenoviral vector, AdCSV, as a control. AdCSV does not contain the gene for E. coli $\beta$-galactosidase.

1. Abbreviations used in this paper: CMV, cytomegalovirus; TBS/T, Tris-buffered saline $10.05 \%$ Tween-20; X-gal, 5-bromo-4-chloro-3-indolyl- $\beta$-D-galactoside. 

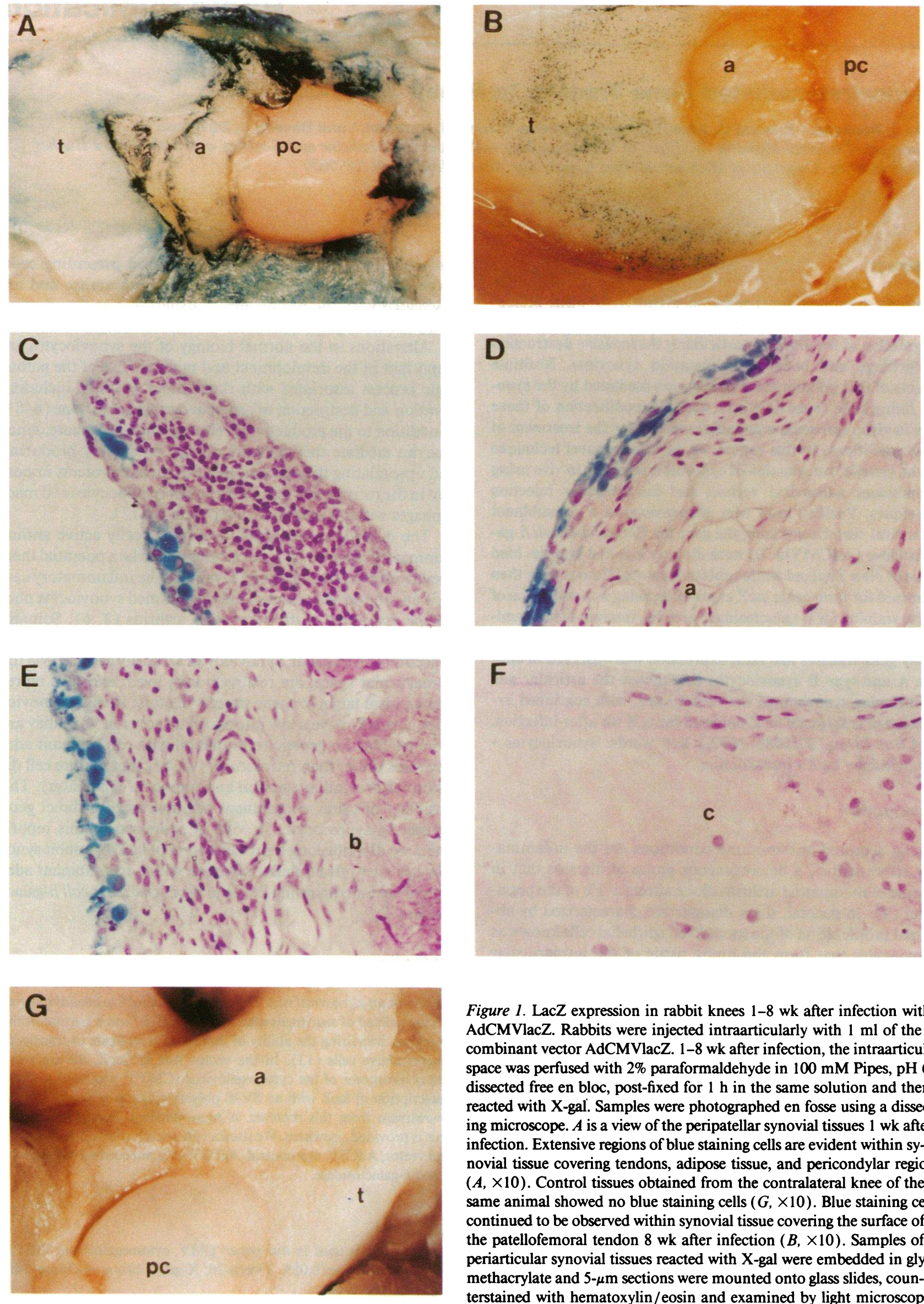

Figure 1. LacZ expression in rabbit knees 1-8 wk after infection with AdCMVlacZ. Rabbits were injected intraarticularly with $1 \mathrm{ml}$ of the recombinant vector AdCMVlacZ. 1-8 wk after infection, the intraarticular space was perfused with $2 \%$ paraformaldehyde in $100 \mathrm{mM}$ Pipes, pH 6.9 , dissected free en bloc, post-fixed for $1 \mathrm{~h}$ in the same solution and then reacted with X-gal. Samples were photographed en fosse using a dissecting microscope. $A$ is a view of the peripatellar synovial tissues 1 wk after infection. Extensive regions of blue staining cells are evident within synovial tissue covering tendons, adipose tissue, and pericondylar regions $(A, \times 10)$. Control tissues obtained from the contralateral knee of the same animal showed no blue staining cells $(G, \times 10)$. Blue staining cells continued to be observed within synovial tissue covering the surface of the patellofemoral tendon $8 \mathrm{wk}$ after infection $(B, \times 10)$. Samples of periarticular synovial tissues reacted with $X$-gal were embedded in glycomethacrylate and 5- $\mu \mathrm{m}$ sections were mounted onto glass slides, counterstained with hematoxylin/eosin and examined by light microscopy. 
High titer recombinant adenovirus was prepared by amplification in LE293 cells using established methods (14). Virus was purified from cell lysates by cesium chloride gradient ultracentrifugation followed by desalting on Sephadex G-50 (Sigma Biochemicals, St. Louis, MO) column in PBS. Purified virus was used immediately for intraarticular injections. Titers ( particles per milliliter) were determined by O.D.260, and were $\sim 1 \times 10^{13}$ particles $/ \mathrm{ml} \pm 1 \log \left(1.0 \mathrm{OD} \mathrm{U}=1.0 \times 10^{12}\right.$ particles $/ \mathrm{ml}$ ).

Animals and intraarticular injections. All animal protocols were approved by the University Committee on the Use and Care of Animals and performed according to institutional guidelines. Male New Zealand white rabbits $2 \mathrm{~kg}$ in weight were used for these experiments. Before the procedure, rabbits were anesthetized with a single intramuscular dose of ketamine/xylazine $(25 \mathrm{mg} / \mathrm{kg}$ ketamine and $5 \mathrm{mg} / \mathrm{kg}$ xylazine), and the area surrounding both hind knees was shaved and prepared with providone/iodine. Using sterile technique and a medial approach, $1 \mathrm{ml}$ of purified AdCMVlacZ suspended in PBS was infused into the intraarticular space of the right knee over a period of $30 \mathrm{~s}$. The left knee was either left uninjected ( $n=3$ rabbits) or was prepared in an identical manner and injected with the control vector AdCSV $(n=4$ rabbits)

In situ staining for $\beta$-galactosidase transgene expression. At 1-8-wk intervals after infection, animals were euthanized with an intravenous overdose of pentobarbital. Both hind knees were infused with $10 \mathrm{ml}$ of $2 \%$ paraformaldehyde in Pipes pH 6.9. Knee joints were removed en bloc, the intraarticular space was exposed by sharp dissection, and samples immersed in the same fixative for one additional hour at $4^{\circ} \mathrm{C}$. Samples were washed twice in PBS/2 $\mathrm{mM} \mathrm{MgCl}_{2}$, and reacted in $5 \mathrm{mM}$ $\mathrm{K}_{3} \mathrm{Fe}(\mathrm{CN})_{6}, 2 \mathrm{mM} \mathrm{MgCl}, 0.01 \%$ sodium deoxycholate, $0.02 \% \mathrm{NP}-40$, and $1 \mathrm{mg} / \mathrm{ml} \mathrm{5-bromo-4-chloro-3-indolyl-} \beta$-D-galactoside (X-gal) in PBS for $30 \mathrm{~min}$ at $37^{\circ} \mathrm{C}(15)$. The intraarticular spaces were then widely exposed by dissection, inspected visually and photographed en fosse using a stereoscopic dissecting microscope (Nikon).

Histology and transmission electron microscopy. Tissues stained with X-gal were processed for routine histology or electron microscopy by postfixing in $2 \%$ glutaraldehyde/PBS. Samples containing bone were decalcified by treatment with $25 \%$ formic acid $/ 7.5 \%$ sodium citrate, neutralized in $5 \%$ sodium sulfate, and further fixed in $2 \%$ glutaraldehyde/PBS. Samples were embedded in glycomethacrylate, and 5$\mu \mathrm{m}$ sections were cut using a microtome, mounted onto glass slides, and counterstained with hematoxylin/eosin. Samples for electron microscopy were postfixed in $2 \%$ glutaraldehyde, $1.5 \%$ paraformaldehyde, and $0.0015 \% \mathrm{CaCl}_{2}$ in $0.1 \mathrm{M} \mathrm{Na}$ cacodylate, followed by $1 \%$ osmium tetroxide in $0.1 \mathrm{M} \mathrm{Na}$ cacodylate containing $5 \%$ sucrose. Samples were then dehydrated in ethanol and embedded in Spurr's medium using previously described methods (16). Articular and periarticular tissues from control knees were processed identically for both light and electron microscopy.

Immunohistochemistry. Samples for immunohistochemical staining were prepared by isolation of the synovial membrane by sharp dissection and fresh freezing in OCT (Miles Inc., Elkhart, IN). Sections $(6 \mu \mathrm{m})$ were prepared on a Bright cryostat and placed onto poly-L-lysine coated slides. Slides were postfixed in methanol at $-20^{\circ} \mathrm{C}$ and blocked by incubation in $1 \%$ BSA/PBS for $1 \mathrm{~h}$ at $20^{\circ} \mathrm{C}$. Slides were then incubated for $1 \mathrm{~h}$ with biotin conjugated to monoclonal (mouse) anti- $\beta$-galactosidase (Sigma), rinsed three times in PBS, and reacted with avidin-AMCA (Vector Labs, Burlingame, CA) for $1 \mathrm{~h}$ at $20^{\circ} \mathrm{C}$. Sections of infected synovium were also reacted with antibodies to adenoviral structural proteins. Incubations were performed for $1 \mathrm{~h}$ at room temperature with FITC-conjugated goat antihexon (Biodesign International, Kennebunkport, ME) or monoclonal (murine) antiade- noviral coat protein (BioGenex Laboratories, San Ramon, CA), followed by incubation with FITC-conjugated goat anti-murine IgG (Vector Labs). After rinsing in PBS, slides were examined and photographed using fluorescent microscopy after excitation with light at 350 $\mathrm{nm}$ (AMCA) or $492 \mathrm{~nm}$ (FITC). Light field photomicrographs were routinely taken of the same fields using Nomarski optics.

Detection of humoral immune response against adenoviral proteins and $E$. coli $\beta$-galactosidase. Serum was obtained from rabbits before intraarticular infection and then at serial time points after infection. These samples were used to detect circulating antibodies directed against recombinant adenoviral structural proteins as well as $E$. coli $\beta$-galactosidase. Aliquots of total viral protein $(1 \mu \mathrm{g})$ obtained from purified preparations of AdBgl II (a recombinant Ad5 derivative that lacks transgene sequences), and aliquots of $E$. coli $\beta$-galactosidase ( 1 $\mu \mathrm{g}$, Sigma) were electrophoresed on $12 \%$ polyacrylamide gels containing $1 \%$ SDS and then transferred to polyvinylidene fluoride membranes (Millipore Corp., Bedford, MA) using a semidry electrophoretic transfer apparatus (Hoefer Scientific Instruments, San Francisco, CA). AdBgl II was purified by double banding through cesium chloride gradients using standard techniques (17). Membranes were blocked by incubation with $1 \%$ nonfat dry milk in TBS, pH 8.0, for $1 \mathrm{~h}$, and then reacted with serum obtained from the cohort of experimental rabbits ( $1: 100$ dilution in TBS, $0.05 \%$ Tween-20 [TBS/T]). Membranes were washed twice in TBS/T and incubated with goat anti-rabbit secondary antibodies conjugated to horseradish peroxidase (1:2000 in TBS/T; Kirkegaard \& Perry Laboratories, Gaitherburg, MD). After two washes in TBS and one wash in PBS, membranes were incubated in enhanced chemiluminescence reagent (Amersham Corp., Arlington Heights, IL) for 1 minute, rinsed, and autoradiographed. The identities of adenoviral structural and nonstructural proteins recognized by cross reactive antibodies present in the serum samples were determined using molecular weight standards (Bio-Rad Laboratories, Hercules, CA) and previously reported data (18).

\section{Results}

In situ staining for $\beta$-galactosidase transgene expression. Visual examination of the intraarticular surfaces of knees injected with the vector AdCMVlacZ showed extensive expression of $\beta$-galactosidase throughout the synovial tissues at $1 \mathrm{wk}$ (Fig. 1 $A$ ) and $\leq 8$ wk (Fig. $1 B$ ) after the administration of AdCMVlacZ. Contralateral control joints that were uninfected or infected with an Ad5 vector that did not contain the gene for $\beta$-galactosidase showed no evidence of blue staining cells at 1 wk (Fig. $1 G$ ) or throughout the experimental period. Qualitatively, the number of lacZ expressing cells throughout the synovium progressively declined from 1 to $8 \mathrm{wk}$ after infection. The number of synoviocytes expressing lacZ activity at 8 wk was estimated to be $\sim 25 \%$ of that observed at $1 \mathrm{wk}$ after injection.

Histology and electron microscopy. Synovial lining cells form a serosal surface that covers multiple types of subsynovial tissue (3-5). Routine histologic examination of articular and periarticular tissues obtained 1 wk after infection with AdCMVlacZ showed X-gal staining cells present within vascular synovial villi, as well as in the synovial tissue covering tendons, bone, articular cartilage, and subsynovial adipose tissue (Fig. 1, $C-F$ ). The cells expressing lacZ activity were synoviocytes as evidenced by typical location and morphologic appear-

Blue staining cells were present within vascular synovial villi $(C)$, synovium covering adipose tissue $(D)$, synovium overlying bone $(E)$, and at the junction of synovium with articular cartilage $(F)$. Microscopic examination confirmed that lacZ expressing cells were confined to the first several layers of cells present within the synovium consistent with the known location of synoviocytes in rabbits. ( $p$, patella; $t$, tendon, $a$, adipose tissue; $c$, cartilage; $b$, bone. 

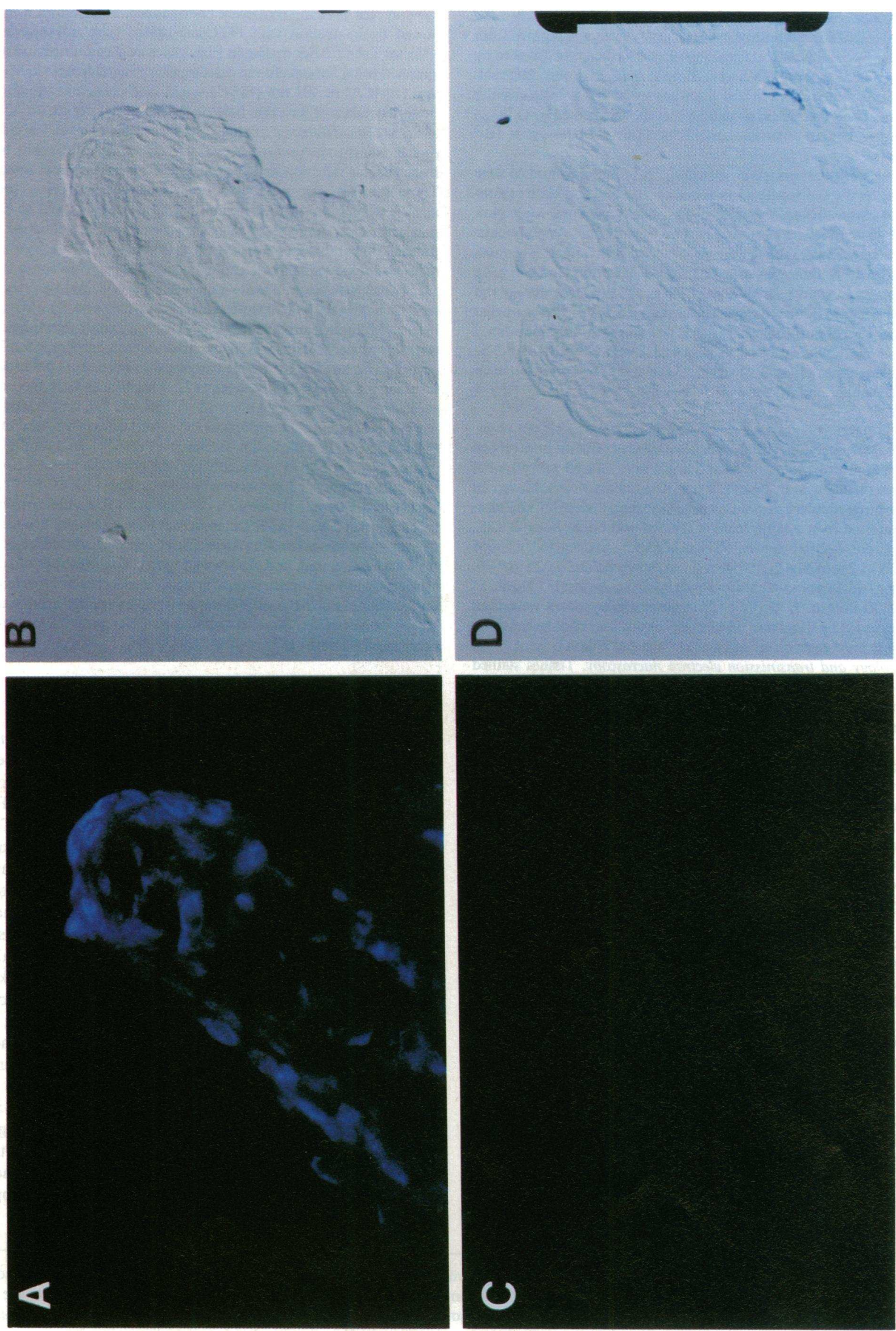
ance. Blue staining cells were confined to the first two to three cell layers in articular and periarticular regions, areas that correspond to the known distribution of synoviocytes in rabbits $(19,20)$.

Type A synoviocytes are thought to be derived from cells of monocyte/macrophage lineage, and therefore may produce significant endogenous levels of lysosomal galactosidase, an enzyme that may react with the $\mathrm{X}$-gal substrate and produce false-positive signals. Specific expression of transgenic $E$. coli lacZ as opposed to endogenous galactosidase activity was confirmed in the infected synoviocytes by immunohistochemical staining using a monoclonal antibody to $E$. coli $\beta$-galactosidase. As shown in Fig. 2, periarticular tissues harvested at 3 wk after infection with AdCMVlacZ continued to show evidence for the specific expression of $E$ : coli $\beta$-galactosidase $(A)$, whereas control samples did not $(C)$.

To identify the lacZ expressing cells as type A or B synoviocytes, transmission electron microscopy (TEM) was performed on infected synovial tissue. Previous studies have shown that TEM can be used to identify the type A and type B synoviocytes in rabbits based on a typical ultrastructural appearance $(21,22)$. Additionally, $X$-gal reaction precipitate can be specifically identified within genetically transduced cells where it appears as dark staining cytoplasmic and perinuclear granules or spicules $(16,23)$. Transmission electron photomicrographs of the periarticular tissues stained with X-gal (Fig. 3 $A$ ) showed intracellular accumulations of X-gal reaction product within both type A and type B rabbit synoviocytes. Both type A synoviocytes, with the characteristic multiple villi and macrophage-like appearance, and type B synoviocytes, more fibroblast-like in appearance, contained the electron-dense granules indicative of $\beta$-galactosidase activity. Control tissues infected with AdCSV showed no intracellular precipitates (Fig. $3 B$ ). Additionally, the ultrastructural appearance of both type $A$ and type B synoviocytes was normal in rabbits infected with AdCMVlacZ or AdCSV and no intranuclear inclusion bodies were observed.

Western blot analysis. A potential concern with the use of adenoviral vectors is the development of a humoral immune response by the host animal. To address this possibility, experiments were performed on sera obtained from the entire experimental cohort ( $n=7$ animals) before and after intraarticular infection with adenoviral vectors. Sera were analyzed by Western blot for the development of antibodies to structural proteins of AdCMVlacZ, as well as to $E$. coli $\beta$-galactosidase (Fig. 4). Low titers of antibodies reactive against several adenoviral structural proteins of Ad5 serotype vector AdBgl II were present in the preimmune sera obtained from all of the experimental animals. (The presence of these antibodies were determined after prolonged exposures of the micrographs.) Increases in the titer of preexisting antibodies, as well as the development of novel antibodies directed against additional adenoviral structural proteins, occurred over the time course of the experiment. Sera from the infected animals consistently cross-reacted with hexon, penton base, hexon associated, and vertex region proteins (18). Cross-reactive antibodies to other adenoviral proteins, such as the 72-kD DNA binding protein, the fiber, and the core proteins were present in sera obtained from some but not all of the experimental rabbits. Two representative Western blots demonstrating cross-reactivity to the various adenoviral proteins are shown in Fig. $4 \mathrm{~A}$. In addition, antibodies directed against $E$. coli $\beta$-galactosidase were observed in one animal (Fig. $4 \mathrm{~B}$ ) in both pre- and postimmune sera.

\section{Discussion}

Previously, recombinant adenoviruses have been demonstrated to mediate expression of foreign transgenes in vivo in a variety of terminally differentiated cell types including neurons, glia, pulmonary epithelium, hepatocytes, and skeletal muscle $(16,24-26)$. In most cases, the efficiency of gene transfer is high, and in many cases, long-term transgene expression has been observed. Recombinant adenoviral vectors are also capable of transferring genes to human synovial cells in vitro (Roessler, B. J., and B. L. Davidson, manuscript in preparation), suggesting that these vectors would be an efficient means for the genetic modification of synoviocytes in vivo.

In these studies, we were able to demonstrate the effectiveness of recombinant adenoviral vectors for the expression of foreign genes by synoviocytes in vivo. The specific expression of lacZ within synovium was confirmed using a combination of in situ staining, immunohistochemistry, and transmission electron microscopy to demonstrate that both type A and type B synoviocytes were genetically transduced and expressed the transgene protein. Although expression within synovial tissues persisted for $\geq 8$ wk after infection, the number of lacZ expressing cells did decline over time. These observations parallel the results obtained in other studies that have used recombinant adenoviral vectors with powerful viral promoters to drive transgene transcription within specific organs in vivo $(16,25)$. The known low rate of synoviocyte proliferation in vivo, combined with the normal histologic appearance of synovial tissues observed at later time points suggests that synoviocyte proliferation with subsequent loss of adenoviral DNA is not a significant mechanism for the loss of transgene expression. Alternative explanations for the progressive decline in lac Z expression observed in vivo include animal to animal variation, alterations in the transcriptional activity of the CMV promoter, direct toxicity of the transgene product, or the development of a neutralizing immune response. A relative persistence of lacZ expressing synoviocytes over tendon and bone compared to the synoviocytes overlying other subsynovial tissues was observed (Fig. $1 B$ ), however the small number of animals examined in this initial study do not allow us to draw conclusions regarding the reasons for this observation. Additional experiments are currently underway to elucidate the reasons for the observed decline in transgene expression and to establish the temporal limits of lacZ activity in rabbit synovium in vivo using a variety

Figure 2. Immunohistochemical localization of lacZ expressing synoviocytes. Specific expression of lacZ in synovium 3 wk after infection with AdCMVlacZ was assessed by AMCA-avidin staining of tissues treated with biotin conjugated monoclonal antibodies to $E$. coli $\beta$-galactosidase. Samples of periarticular synovial tissues were isolated by sharp dissection and frozen in OCT. Cryostat sections $(6 \mu \mathrm{m})$ were treated as described in Methods. AMCA-positive (blue) synoviocytes are evident at $3 \mathrm{wk}$ after infection in samples treated with $1^{\circ}$ antibody $(A)$, but not in control samples ( $C$, no $1^{\circ}$ antibody) confirming the histochemical results demonstrated in Fig. 1. $A$ and $C$, fluorescence photomicrographs of synovial cells; $B$ and $D$, light photomicrographs taken with Nomarski optics from the same field as $A$ and $C$, respectively. $\times 400$. 

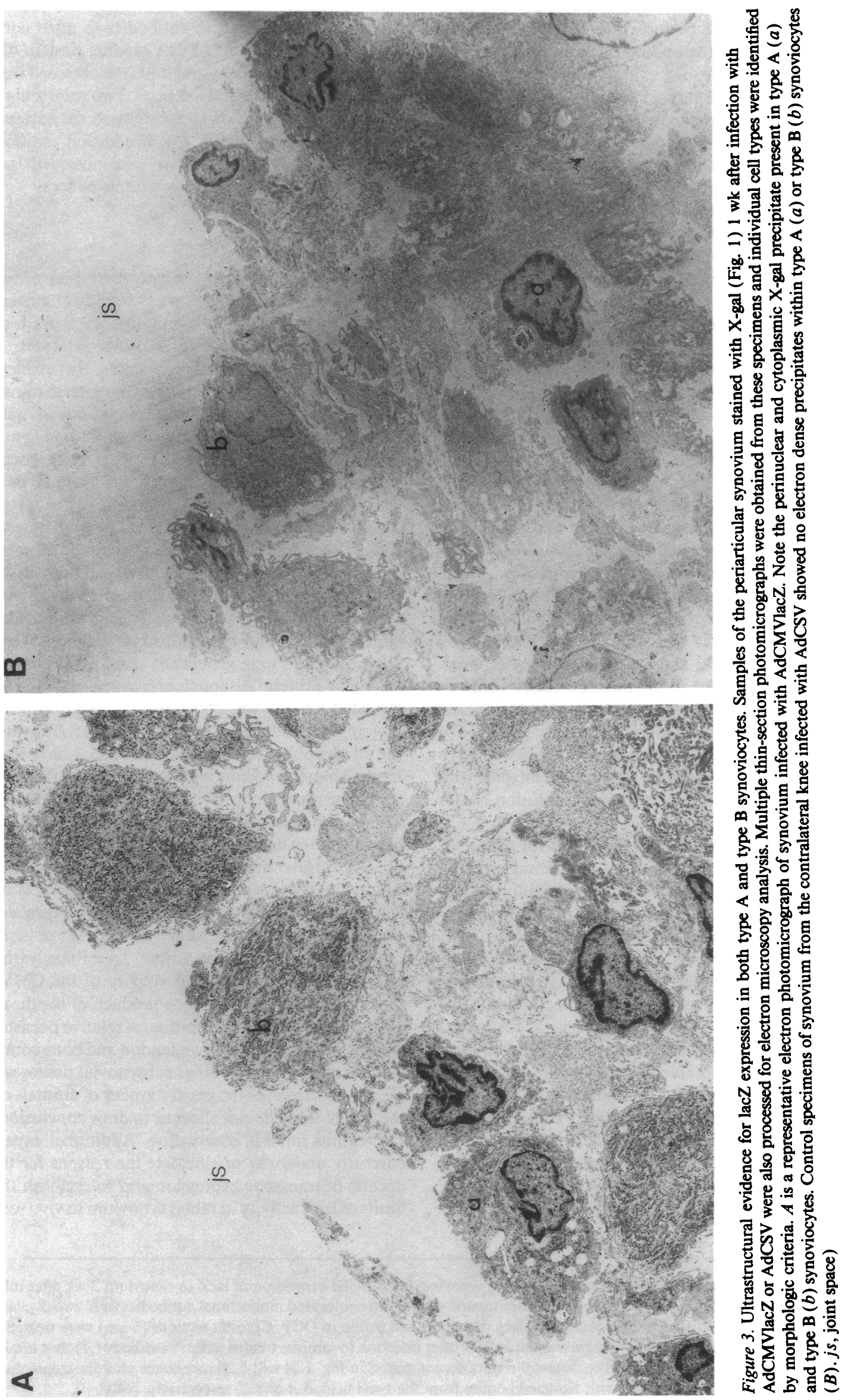


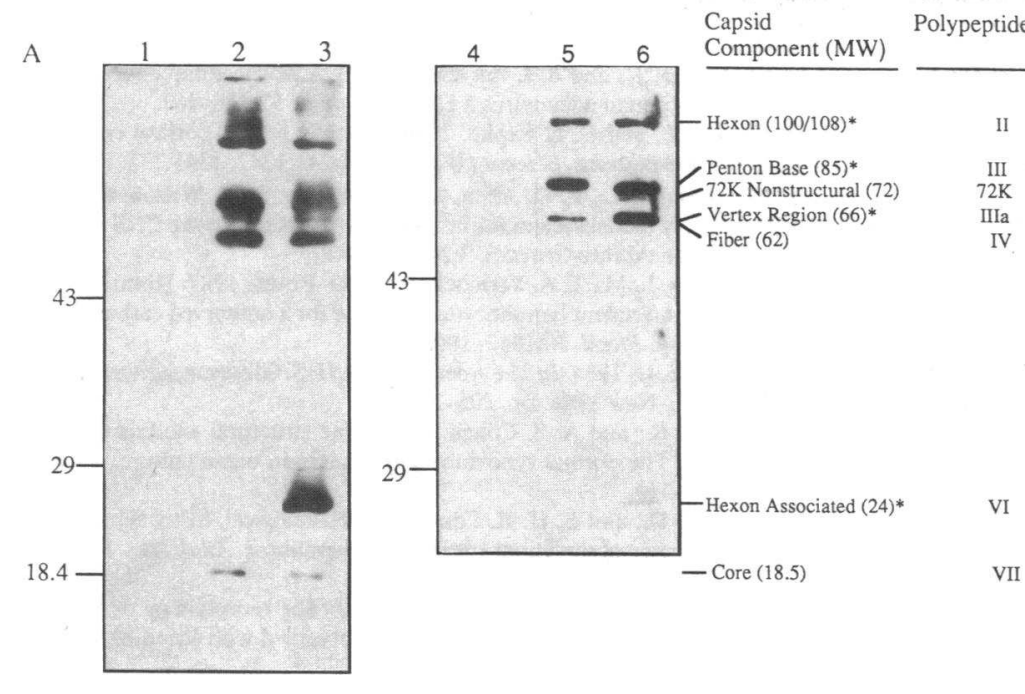

Figure 4. Detection of circulating antibodies to $E$. coli $\beta$-galactosidase and adenoviral structural proteins in rabbits after intraarticular injection of AdCMVlacZ. Sera was collected from all seven experimental animals before injection, $2 \mathrm{wk}$ after infection, and at the time of death. Western blotting was done after SDS/PAGE of $1 \mu \mathrm{g}$ of purified AdBgl II (recombinant Ad5 derivative; $A$ ) or $1 \mu \mathrm{g}$ of purified $E$. coli $\beta$-galactosidase $(B)$ as described in Methods. $A$ shows two representative blots incubated with sera (diluted 1:100) from rabbit 4 (lanes $1-3: 1=$ preimmune, $2=2 \mathrm{wk}$ after infection, $3=4$ wk after infection), and rabbit 3 (lanes 4-6: $4=$ preimmune, $5=2 \mathrm{wk}$ after infection, $6=3 \mathrm{wk}$ after infection). Overexposure of the autofluorographs allowed identification of antibodies specifically directed against adenoviral structural proteins (primarily penton base protein) present in the preimmune sera obtained from all animals (data not shown). In every case, infected animals exhibited progressive qualitative increases in the titers of circulating antiadenoviral antibodies by 2 wk after infection $(A$, lanes 2 and $5 ; B$, lane 2). The identity of the adenoviral capsid or nonstructural components recognized by antibodies present in the serum samples are indicated on the right border of $A$, along with the respective polypeptide numbers and molecular weights (kilodaltons). In $B$, antibodies against $\beta$-galactosidase were detected in preimmune and postimmune sera from rabbit 4 , with titer increasing over time ( $1=$ preimmune, $2=2$ wk after infection, $3=4 \mathrm{wk}$ after infection)

of recombinant adenoviral vectors containing the gene for $E$. coli lacZ.

Clinically, the experimental cohort of rabbits showed no evidence of arthritis or synovitis within the infected hind knees throughout the experimental period, and there was no evidence of disease or severe inflammation on histopathologic examination of tissues $\leq 8 \mathrm{wk}$ after infection. Additionally, no adverse systemic side effects were observed in animals infected with either AdCMVlacZ or AdCSV.

The development of antibodies directed against adenoviral structural proteins and a foreign transgene by the host animals is not unexpected. Adenoviruses are ubiquitous amongst animal species and rabbit adenoviruses have been isolated and characterized $(27,28)$. Cross-reactive antibodies to bovine adenoviruses in sera obtained from naive rabbits have previously been described (29). Additionally, rabbits immunized with human adenoviruses can produce neutralizing antibodies crossreactive to endogenous rabbit adenoviruses (30). The presence of antibodies against AdCMVlacZ proteins in rabbits before intraarticular infection, and the rapid development (within 1-2 wk) of a high titer against AdCMVlacZ proteins, suggests that members of this experimental cohort had been exposed previously to rabbit or human adenoviruses, despite maintenance in pathogen specific free housing. The time course of the systemic humoral immune response is most consistent with an amnestic IgG production. Similarly, the intestines of rabbits are colonized with species of $E$. coli that produce endogenous levels of $\beta$-galactosidase and other bacterial proteins that are capable of eliciting a systemic humoral immune response (31). This is a possible explanation for the observation that at least one animal within the experimental group of seven animals developed high titers of antibodies directed against the transgenic lacZ protein. A more comprehensive understanding of the dynamics of the immune response to adenoviral vectors in host animals previously exposed to wild type adenoviruses will be important in development of recombinant adenoviral vectors for potential therapeutic uses.

Because synoviocytes play a key role in the pathophysiology of joint inflammation, they are potential target cells for gene therapy techniques aimed at the treatment of inflammatory arthropathies via the directed over-expression of antiinflammatory proteins. Although these experiments used $E$. coli lacZ as a functional transgene, recombinant adenoviral vectors containing the cDNA for syngeneic antiinflammatory proteins could be constructed and used for intraarticular injection using an identical methodology. The interleukin-1 receptor antagonist protein is a naturally occurring molecule that may ameliorate multiple aspects of the inflammatory response associated 
with the expression of interleukin- $1 \beta$ within rheumatoid synovium (32-37). This molecule is endogenously expressed by human synoviocytes, and represents a reasonable candidate for therapeutic over-expression via direct in vivo infection of synoviocytes with recombinant adenoviral vectors $(32,37)$.

Ex vivo gene transfer using recombinant retroviruses to cells derived from type $B$ rabbit synoviocytes has been reported, however the efficiency of gene transfer is relatively low, and the technique is laborious (38). In contrast, the use of recombinant adenoviral vectors for intraarticular infection is relatively simple and results in the efficient genetic transduction of both types of synovial lining cells, with persistence of transgene expression for $\geq 8 \mathrm{wk}$ after infection. The results of these studies suggest that direct genetic modification of synoviocytes using adenoviral vectors in vivo may be a superior method for the intraarticular delivery of potentially therapeutic antiinflammatory proteins.

\section{Acknowledgements}

The authors wish to thank C. William Castor, M.D., for critical evaluation of synoviocytes at the ultrastructural level, Jill Latta and Lorita Dudus for expert technical assistance, and Jeanne-Marie Quevedo for expert secretarial assistance. B. L. Davidson is a fellow of the National Arthritis Foundation. This work was supported in part by the National Institutes of Health (PO1DK42718).

\section{References}

1. Harris, E. D., Jr. 1990. Rheumatoid arthritis. Pathophysiology and implications for therapy. (Published erratum appears in N. Engl. J. Med. 1990. 323:996) N. Engl. J. Med. 322:1277-1289.

2. Remmers, E. F., R. Lafyatis, G. K. Kumkumian, J. P. Case, A. B. Roberts, M. B. Sporn, and R. L. Wilder. 1990. Cytokines and growth regulation of synoviocytes from patients with rheumatoid arthritis and rats with streptococcal cell wall arthritis. Growth Factors. 2:179-188.

3. Barland, P., A. B. Novikoff, and D. Hamerman. 1962. Electron microscopy of the human synovial membrane. J. Cell Biol. 14:207-220.

4. Krey, P. R., A. S. Cohen, C. B. Smith, and M. Finland. 1971. The human fetal synovium. Histology, fine structure and changes in organ culture. Arthritis Rheum. 14:319-341.

5. Pitsillides, A. A., and S. M. Blake. 1992. Uridine diphosphoglucose dehydrogenase activity in synovial lining cells in the experimental antigen induced model of rheumatoid arthritis: An indication of synovial lining cell function. Ann Rheum. Dis. 51:992-995.

6. Yocum, D. E., R. Lafyatis, E. F. Remmers, H. R. Schumacher, and R. L. Wilder. 1988. Hyperplastic synoviocytes from rats with streptococcal cell wall-induced arthritis exhibit a transformed phenotype that is thymic-dependent and retinoid inhibitable. Am. J. Pathol. 132:38-48.

7. Redini, F., C. Lafuma, J. P. Pujol, L. Robert, and W. Hornebeck. 1988 Effect of cytokines and growth factors on the expression of elastase activity by human synoviocytes, dermal fibroblasts and rabbit articular chondrocytes. Biochem. Biophys. Res. Commun. 155:786-793.

8. Brinckerhoff, C. E., and E. D. Harris, Jr. 1978. Collagen production by cultures containing multinucleated cells derived from synovial fibroblasts. Arthritis Rheum. 21:745-753.

9. Burmester, G. R., B. Jahn, P. Rohwer, J. Zacher, R. J. Winchester, and J. R. Kalden. 1987. Differential expression of Ia antigens by rheumatoid synovial lining cells. J. Clin. Invest. 80:595-604.

10. Morales-Ducret, J., E. Wayner, M. J. Elices, J. M. Alvaro-Gracia, N. J. Zvaifler, and G. S. Firestein. 1992. Alpha 4/beta 1 integrin (VLA-4) ligands in arthritis. Vascular cell adhesion molecule-1 expression in synovium and on fibroblast-like synoviocytes. J. Immunol. 149:1424-1431.

11. Chu, C. Q., M. Field, M. Feldmann, and R. N. Maini. 1991. Localization of tumor necrosis factor alpha in synovial tissues and at the cartilage-pannus junction in patients with rheumatoid arthritis. Arthritis Rheum. 34:1125-1132.

12. Lindsley, H. B., D. D. Smith, L. S. Davis, A. E. Koch, and P. E. Lipsky. 1992. Regulation of the expression of adhesion molecules by human synoviocytes. Semin. Arthritis Rheum. 21:330-334.

13. Hurwitz, D. R., and G. Chinnadurai. 1985. Evidence that a second tumor antigen coded by adenovirus early gene region E1a is required for efficient cell transformation. Proc. Natl. Acad. Sci. USA. 82:163-167.

14. Graham, F. L., and A. J. van der Eb. 1973. A new technique for the assay of infectivity of human adenovirus 5 DNA. Virology. 52:456-467.

15. Walsh, C., and C. L. Cepko. 1988. Clonally related cortical cells show several migration patterns. Science (Wash. DC). 241:1342-1345.

16. Davidson, B. L., E. D. Allen, K. F. Kozarsky, J. M. Wilson, and B. J. Roessler. 1993. A model system for in vivo gene transfer into the CNS using an adenoviral vector. Nature Genetics. 3:219-223.

17. Stoolman, L. M., T. A. Yednock, and S. D. Rosen. 1987. Homing receptors on human and rodent lymphocytes-evidence for a conserved carbohydratebinding specificity. Blood. 70:1842-1850.

18. Pettersson, U. 1984. In The Adenoviruses. H. S. Ginsburg, editor. Plenum Publishing Corp., New York. pp. 205-229.

19. Krey, P. R., and A. S. Cohen. 1973. Fine structural analysis of rabbit synovial cells. I. The normal synovium and changes in organ culture. Arthritis Rheum. 16:324-340.

20. Lever, J. D., and E. H. R. Ford. 1958. Histological, histochemical and electron microscopic observations on synovial membrane. Anat. Rec. 132:525537.

21. Steinberg, P. J., and K. C. Hodde. 1990. The morphology of synovial lining of various structures in several species as observed with scanning electron microscopy. Scanning Microsc. 4:987-1019.

22. Levanon, D., and H. Stein. 1992. The synovial lining of the rabbit knee: a scanning electron microscopy study of specimens reinforced structurally with tannic acid. Histochem. J. 24:25-32.

23. Engelhardt, J. F., E. D. Allen, and J. M. Wilson. 1991. Reconstitution of tracheal grafts with a genetically modified epithelium. Proc. Natl. Acad. Sci. USA. 88:11192-11196.

24. Rosenfeld, M. A., K. Yoshimura, B. C. Trapnell, K. Yoneyama, E. R. Rosenthal, W. Dalemans, M. Fukayama, J. Bargon, L. E. Stier, L. Stratford-Perricaudet, et al. 1992. In vivo transfer of the human cystic fibrosis transmembrane conductance regulator gene to the airway epithelium. Cell. 68:143-155.

25. Jaffe, H. A., C. Danel, G. Longenecker, M. Metzger, Y. Setoguchi, M. Rosenfeld, T. Gant, S. S. Thorgeirsson, L. Stratford-Perricaudet, M. Perricaudet, et al. 1992. Adenovirus-mediated in vivo gene transfer and expression in normal rat liver. Nature Genetics. 1:372-378.

26. Quantin, B., L. D. Perricaudet, S. Tajbakhsh, and J. L. Mandel. 1992. Adenovirus as an expression vector in muscle cells in vivo. Proc. Natl. Acad. Sci. USA. 89:2581-2584.

27. Bodon, L., L. Prohaszka, E. Adam, and I. Nasz. 1979. Isolation of adenoviruses from rabbits. Acta Vet. Hung. 27:73-75.

28. Bodon, L., and L. Prohaszka. 1980. Isolation of an adenovirus from rabbits with diarrhoea. Acta Vet. Hung. 28:247-255.

29. Descoteaux, J. P., K. Whissel, and R. Assaf. 1980. Detection of antibody titers to bovine viruses in rabbit sera. Lab. Anim. Sci. 30:581-582.

30. Bodon, L., L. Zsak, and E. Nagy. 1980. Detection of neutralizing antibodies to genuine rabbit adenovirus in rabbit antisera to human adenoviruses. Acta Vet. Acad. Sci. Hung. 28:399-402.

31. Mierendorf, R. C., C. Percy, and R. A. Young. 1987. Gene isolation by screening lambda-gt 11 libraries with antibodies. In Guide to Molecular Cloning Techniques. S. L. Berger and A. R. Kimmel, editors. Academic Press, Inc., San Diego, CA. pp. 458-469.

32. Dinarello, C. A. 1992. Reduction of inflammation by decreasing production of interleukin-1 or by specific receptor antagonism. Int. J. Tissue React. 14:65-75.

33. Carter, D. B., M. R. Deibel, Jr., C. J. Dunn, C. S. Tomich, A. L. Laborde, J. L. Slightom, A. E. Berger, M. J. Bienkowski, F. F. Sun, R. N. McEwan, et al. 1990. Purification, cloning, expression and biological characterization of an interleukin-1 receptor antagonist protein. Nature (Lond.). 344:633-638.

34. Eisenberg, S. P., R. J. Evans, W. P. Arend, E. Verderber, M. T. Brewer, C. H. Hannum, and R. C. Thompson. 1990. Primary structure and functional expression from complementary DNA of a human interleukin-1 receptor antagonist. Nature (Lond.). 343:341-346.

35. Arend, W. P., H. G. Welgus, R. C. Thompson, and S. P. Eisenberg. 1990. Biological properties of recombinant human monocyte-derived interleukin-1 receptor antagonist. J. Clin. Invest. 85:1694-1697.

36. Haskill, S., G. Martin, L. Van Le, J. Morris, A. Peace, C. F. Bigler, G. J. Jaffe, C. Hammerberg, S. A. Sporn, S. Fong, et al. 1991. cDNA cloning of an intracellular form of the human interleukin-1 receptor antagonist associated with epithelium. Proc. Natl. Acad. Sci. USA. 88:3681-3685.

37. Koch, A. E., S. L. Kunkel, S. W. Chensue, G. K. Haines, and R. M. Strieter. 1992. Expression of interleukin-1 and interleukin-1 receptor antagonist by human rheumatoid synovial tissue macrophages. Clin. Immunol. Immunopathol. 65:23-29.

38. Bandara, G., P. D. Robbins, H. I. Georgescu, G. M. Mueller, J. C. Glorioso, and C. H. Evans. 1992. Gene transfer to synoviocytes: prospects for gene treatment of arthritis. DNA Cell Biol. 11:227-231. 